\title{
MY STYLE IS MY THINKING
}

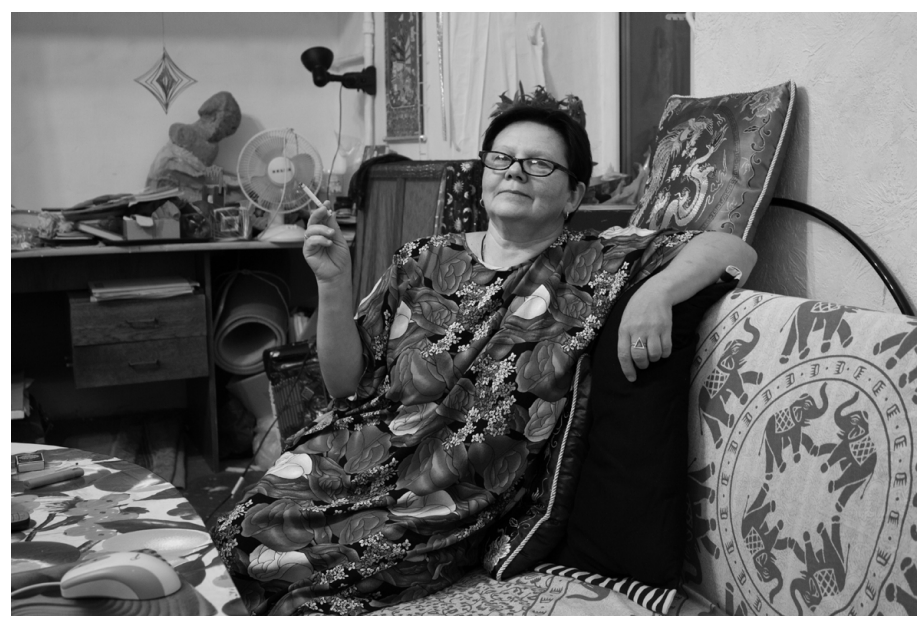

LARISA ZVEZDOTSHETOVA TYÖHUONEENSSAAN ODESSASSA 1.9.2012. VALOKUVA: KIMMO SARJE.

Larisa Zvezdotshetova (s. 1958) on syntyperäinen odessalainen kuvataiteilija, jonka taiteelliseen kehitykseen elämä perestroikan ajan Moskovassa vaikutti ratkaisevasti. Hän toimi 1980-luvun lopulla kokonaista taiteilijasukupolvea muovanneessa Furmanni-kujan yhteisössä. Huonetilojen purkamista odottaneessa vanhassa asuinkerrostalossa Moskovan keskustassa työskenteli yli seitsemänkymmetä taiteilijaa naivisteista käsitetaiteilijoihin.”Furmanni oli elämäni parasta aikaa”, Zvezdotshetova muistelee.

Käsitteellisesti tai filosofisesti suuntautuneista taiteilijoista Sven Gundlah, Vladimir Mironenko, Andrei Filippov, Juri Albert ja Zvezdotshetovan silloinen aviomies Konstantin Zvezdotshetov olivat hänen läheisimpiä kollegoitaan. Furmanni oli epävirallinen taidekoulu, jossa taiteilijat oppivat toisiltaan. Zvezdotshetova korostaakin, että hänen sukupolvensa taiteilijoilla oli harvoin varsinaista ammattikoulutusta."Kukaan ei pakottanut meitä hyviksi maalareiksi tai piirtäjksi. Tutkimme taidehistoriaa ja -teoriaa, samalla kun neuvostoakatemiat kahlitsivat kaiken käsityöhön.”Tästä huolimatta kaksi kolmasosaa Furmannin taiteilijoista toimii yhä alalla.

Mutta kuinka nuori naistaiteilija otti tilansa miehisessä yhteisössä? ”Olin sellainen monsteri”, hän sanoo. "En ole feministi. Minulle feminismi on jonkinlainen getto. Voisin myös sanoa, että jokainen nainen on feministi, kun hän ottaa asemansa."

Taiteilijana Zvezdotshetovaa kiinnostavat esteettiset kokeet, uudet tekniikat ja materiaalit, kitsch ja nykyajan arkeologia. Myös naiseuteen liittyvät teemat kuten koti ovat aika ajoin tärkeitä hänen työssään. "My style is my thinking."

Neuvostoaikana Odessa oli yksi unionin kiinnostavia taidekaupunkeja Moskovan ja Leningradin ohella.Moskovan vuosien jälkeen Länsi-Euroopassa toiminut Zvezdotshetova on palannut ja asettunut nykyisin Ukrainaan kuuluvaan Odessaan, vaikka hänellä onkin Venäjän ja Hollannin kansalaisuus.

Pekka Halosen taidekokoelmaan sisältyy merkittävä otos Furmanni-kujan sots-taidetta perestroikan vuosilta. Myös Zvezhdotshetova on mukana parilla varhaisella teoksellaan. 